\title{
EFFECTIVE FOREIGN LANGUAGE TRAINING THROUGH EDUCATIONAL TECHNOLOGY WITH THE USE OF DICTIONARIES
}

\author{
Valentyna Kyrykylytsia \\ Lesya Ukrainka Eastern European National University, Lutsk, Ukraine \\ valentina.kirikilica@gmail.com
}

\begin{abstract}
The article introduces the educational technology with the use of dictionaries into the process of foreign language training of the students of non-linguistic specialties. The author defines this technology as an algorithm of teachers and students' common actions aimed at formation the abilities and skills of working with dictionaries of different types, learning the information obtained from dictionaries and its usage in the further practical activity. The paper demonstrates the convincing superiority of the newly developed technology which, under methodically correct conditions of its application, can significantly improve the qualitative indicators of the educational process. This hypothesis was confirmed by the results of the research conducted in 2016/2017 academic year at nonlinguistic faculties of Lesya Ukrainka Eastern European National University. 183 first- and second-year students, among them 92 students of the experimental group (EG) and 91 students of the control group (CG), were involved in the research. The study of the discipline "Profession-Oriented Foreign Language Study" in EG was carried out in the form of experimental teaching by means of the suggested technology while in CG traditional methods of teaching were used. The comparison of the students' knowledge results obtained before and after the experiment allows us to state that there is a substantial increase in foreign language proficiency of EG students compared with the students in CG. This paper mainly presents the idea that application of the suggested technology ensures continuity and consistency of a foreign language acquisition, and a gradual transition from training to future professional activities.
\end{abstract}

Keywords: foreign language training; the students of non-linguistic specialties; dictionary; abilities and skills; dictionary activity; educational technology with the use of dictionaries.

\section{Introduction}

In recent years the status of foreign languages has considerably changed in the Ukrainian society. The economic and socio-cultural situation in the country as well as the integration processes of Ukraine into the world community has provided a huge demand for knowledge of foreign languages and created a strong motivation for their study.

The necessity of effective foreign language training in higher educational institutions is stated not only by educators, but also by the officials who consider the implementation of the European standards of teaching and learning foreign languages. For example, the recommendation letter of the Ministry of Education and Science of Ukraine (Standards Ukraine, 2015) stresses that it is needed to create favourable conditions for learning the English language as a language of international academic communication in order to achieve B2 level by the university graduates according to the Common European Framework of Reference for Languages. Therefore, within the period of 4 academic years, there should be introduced such a mechanism of foreign languages training at non-linguistic faculties so that a graduate could easily pass a Common European test to obtain B2 level.

Currently, the real situation regarding the level of foreign language knowledge by the students of nonlinguistic specialties who begin their foreign language course in higher educational institutions does not look so optimistic. The practice of teaching foreign languages in a higher school and the survey conducted among the first year students of Lesya Ukrainka Eastern European National University testify that their linguistic level leaves much to be desired. Unfortunately, an average secondary school graduate, who starts his/her course of study at a Bachelor degree at university, achieves the level of an elementary user A1 or A2 in a foreign language. Certainly, the available B1 level can be observed only among secondary schools graduates with advanced study of foreign languages, graduates of specialised schools or those ones who studied a foreign language with tutors.

Having analysed the works dedicated to the problem of foreign language teaching and learning by such scientists as Harmer (2007), Kitaygorodskaya (1986), Nikolaieva (2008), Panova (2010), Rogova (1991), Tarnopolskyi (2006), Vyshnevskyi (2011) who interpreted a foreign language as a subject that has a great educational, developmental and educational potential, we would like to focus our attention on the fact that this academic discipline, on the one hand, forms the basis for the general culture of a personality, and, on the other hand, helps future specialists to master a field of knowledge related to their professional activity.

The problem of foreign language training of the students of non-linguistic specialties has been studied by many researchers (Mykytenko, 2011; Nikolayenko, 2013; Pasichnyk, 2014; Synekop, 2015) who claim that the term "foreign language training" is a general term that embraces foreign language teaching and learning as well as foreign language education in which students are involved to increase their language achievement and proficiency. 
Although the issue of effective foreign language training holds an important place in scientific research, it needs further investigation in connection with the growth of the requirements for the quality of foreign language education. For this purpose, pedagogical science is tasked to create an effective educational system based on the use of innovative educational technologies and methods of training which would be able to engage students in the process of acquiring foreign language knowledge, abilities and skills. As reported by U.S. Department of Education Office of Educational Technology (2014), student access to technology is no longer a privilege: it is a prerequisite for full participation in high-quality education opportunities (p. 3).

Providing students with thorough knowledge and practical skills in the process of teaching a foreign language is impossible without the use of dictionaries. Dictionaries are considered to be of great value to education in general and to foreign language training in particular. Taking into account the value of dictionaries in spreading knowledge and culture, Landau (2012) states that the term "dictionary" is powerful and suggests authority, scholarship and precision (p. 21).

The problem of dictionary usage requires its study as a single complete system different components of which are dialectically interacted. We share the standpoint of Harmer (2004) who believes that if we want students to use dictionaries it will probably not be sufficient just to recommend a dictionary and tell them how useful it is. Many teachers put dictionary training into lesson sequences, so that students will see how to use them and what the benefits of such use are (p. 171). If students learn how to use a dictionary effectively, then a dictionary can become a very helpful resource for their studies.

A profound analysis of the fundamentals of the technological approach in education (Abasova, 2013; Bondar, 2005; Borko, 2009; Nisimchuk, 2000; Piekhota, 2001; Polat, 2002;) made it possible to formulate the notion of educational technology with the use of dictionaries which is regarded as an algorithm of teachers and students' common actions aimed at formation the abilities and skills of working with different types of dictionaries, learning the information obtained from dictionaries and its usage in the further practical activity (Kyrykylytsia, 2013, p. 7).

The article aims to analyse the impact of educational technology with the use of dictionaries on the process of foreign language training of the students of non-linguistic specialties. To achieve this goal the following tasks are faced: 1) gradual implementation of educational technology with the use of dictionaries at the foreign language classes; 2) experimental verification of the impact of the suggested technology on the students' knowledge results.

In this research, it is hypothesised that foreign language training of the students of non-linguistic specialties will be more resultative through application of educational technology with the use of dictionaries, which will create conditions for full, effective and consequent acquisition of foreign language knowledge, abilities and skills by the students of non-linguistic specialties.

\section{Methods}

The study was conducted on the basis of the faculties of non-linguistic specialties of Lesya Ukrainka Eastern European National University during the 2016-2017 academic year. It became a continuation of the research work carried out by the author during many years of teaching activity. The research involved 4 teachers and 183 first and second-year students studying at the bachelor's educational programme at the faculties of: Economics and Management; Information Systems, Physics and Mathematics; Physical Culture, Sports and Health; Geographical and Chemical faculties. Among them, there were 92 students of the experimental group (EG) and 91 students of the control group (CG). Most students study a foreign language for $10-12$ years $(90 \%)$, the rest - for 6-9 years $(10 \%)$. During the academic year the discipline "ProfessionOriented Foreign Language Study" covered 70 academic hours per first course at each specialty and 62 academic hours per second course at each specialty, that is, about 2 academic hours per week.

When forming EG and CG, we became acquainted with the university educational curricula for foreign languages study in the selected groups; with evaluative judgements of the teachers who taught the students of those groups; with the grades of academic progress of the second-year students in the subject "ProfessionOriented Foreign Language Study" within the previous academic year, and with the level of foreign language proficiency of the first year students with the help of the test "Find out Your Foreign Language Level".

Consequently, we can state that there were equal conditions in EG and CG as well as approximately the same quantitative and qualitative contingent of the participants in the experiment. Only teaching methods in both groups were different. In EG the active factor of impact was put into operation, namely the study of the discipline "Profession-Oriented Foreign Language Study" was carried out with the systematic application of the educational technology with the use of dictionaries, and with the help of the study guide "English with Dictionaries Use for the Students of Chemistry" (Kyrykylytsia, 2016), which presents a wide range of tasks that must be done with the use of dictionaries of different types. In CG the educational process remained 
unchanged, the subject "Profession-Oriented Foreign Language Study" was taught according to traditional, common methodology, which is characterised by the fragmentary usage of dictionaries.

The implementation of educational technology with the use of dictionaries as a form of experimental teaching in EG was carried out step-by-step throughout the entire academic year and consisted of 5 consecutive interrelated stages:

At the preparatory (motivational) stage, which began and took place at the first foreign language classes at university, the teacher familiarised students with the dictionaries of different types, formed students' awareness of the importance of dictionaries, developed students' motivation and interest to use dictionary editions. The teacher used such forms and methods of activity as conversations about different types of dictionaries and their role in the study of special subjects, disputes about the expediency of using dictionary editions, projects design on the history of dictionaries creation, etc.

At the introductory (informational) stage, that occurred at the next 2 or 3 lessons, the students were informed about the structure of a dictionary and the way of a word presentation in a dictionary (e.g. alphabetical) as well as about lexicographical notes. The teacher checked up students' knowledge of the alphabet and transcription, and, finally, students get acquainted with the organisation of the material inside a dictionary entry. Thus, the teacher laid the foundation for the formation of abilities and skills of dictionary activity.

At the practical (operational) stage, which lasted during the first term, all the students were involved into the rapid search for necessary information in a dictionary during classroom lessons under a teacher's supervision. Then, if there was time, students could exercise the analogical activity independently in order to develop abilities and skills of working with a dictionary and to avoid problems of dictionary usage during their further autonomous activity.

For a fundamental (procedural) stage, which took place in the second term, the following methods of working with a dictionary were used: analysis, synthesis, comparison, generalisation, classification and systematisation of information from a dictionary. Such an activity provided the formation of students' foreign language knowledge as well as consolidation of their previously formed abilities and skills of working with the dictionaries of different types. At this stage, the teacher recorded some negative points in students' dictionary activity and helped them overcome difficulties connected with the use of dictionaries.

The main task of a conclusive (resultative) stage at the end of the second term was the awareness by the students of their dictionary activity, its reflection and correction as well as their self-assessment and teacher's assessment of the development of students' abilities and skills of working with dictionaries.

To achieve the purpose of the research the complex methods were used: 1) pedagogical observation of students' learning activities at foreign language classes, questionnaires, conversations and interviews helped to find out students' attitude to dictionaries usage, to dictionary activities and to acquisition of abilities and skills of working with a dictionary during a foreign language study as well as difficulties that arise in the process of working with dictionaries; 2) ranking method allowed to determine students' opinion on the types of dictionaries and the types of dictionary activity which are most (least) useful when learning a foreign language; 3) testing method was used for final students' knowledge quality control; 4) method of pedagogical experiment was applied to verify the validity of the proposed pedagogical hypothesis; 5) method of mathematical statistics (Student's criterion) was used for processing the empirical data. The optimal combination of the whole set of methods ensured the reliability of the research results.

\section{Results and Discussion}

Many years of foreign language teaching experience and research results convincingly prove that students, especially first-year students, require both theoretical training to work with a dictionary and practical dictionary activity at the foreign language classes.

One of the tasks of the study was to find out students' understanding of the significance of a dictionary, their attitude to dictionary activity, students' awareness of the necessity of obtaining abilities and skills of working with a dictionary for successful foreign language study.

First of all, it should be noted that before and after the experiment, students showed almost identical results in understanding the importance of a dictionary and in their attitude to dictionary activity. The majority of students are convinced that "dictionary is important for the study of a foreign language" (about $86 \%$ of EG students and $85 \%$ of those in CG). The students of EG and CG almost equally agree with the statement that "completing the tasks with the use of a dictionary helps to upgrade knowledge of a foreign language and of a chosen specialty" (about $68 \%$ of EG students and 65\% of those in CG). Such answers allow us to indicate a certain tendency in understanding by a modern student the necessity of dictionary usage, when learning a foreign language, for personal development and professional formation. 
However, at the end of the experiment, in EG the number of students who believe that "dictionary skills require training and practice" are prevalent (52,5\% of EG students and 32,3\% of CG students). A similar picture is also observed in students' understanding that "the ability to work with a dictionary is compulsory for perfect foreign language acquisition" (78,2\% of students in EG and 47,3\% of CG students). Moreover, the implementation of educational technology with the use of dictionaries in EG allowed students to form interest in dictionary activity: $26,9 \%$ of students in EG, compared with $5,6 \%$ in CG, believe that "dictionary activity is interesting and exciting".

The obtained results show that, on the one hand, there is some positive experience regarding the use of dictionaries in the process of foreign languages training at universities, but, on the other hand, we can experience the lack of systematic, purposeful activity of teachers and students in this direction. We believe that when students realise the need for systematic use of dictionaries as a means of learning, it will help to create a sustainable motivational basis for their usage in the process of further education. In addition, the use of dictionaries as a means of training should be envisaged in all educational curricula for the academic discipline "Profession-Oriented Foreign Language Study" at each course and each non-linguistic specialty.

Carrying out the pedagogical experiment, we investigated how the first and second-year students of non-linguistic specialties understand the potential of different types of dictionaries, especially dictionaries for special purposes, in the formation of professional knowledge. After all, students' activity in the process of working with a dictionary includes the features of not only educational, but also of future professional value. At the beginning of the experiment, most students, both in EG and CG, indicated that in their learning activity they mainly use bilingual dictionaries (89\% of students in EG and $91 \%$ of those in CG), very rarely monolingual dictionaries (9\% of EG students and 7\% of those in CG), and almost never - special ones (2\% of students equally in EG and CG). But, at the end of the experiment, there occured significant changes in students' understanding of the importance of different types of dictionaries used when learning a foreign language. The results are presented in Table 1 on a scale from 5 to 1 (5-most useful, 1 - least useful):

Table 1

Students' assessment of different types of dictionaries used in the process of foreign language training

\begin{tabular}{|c|c|c|c|c|c|c|c|c|c|c|c|}
\hline \multirow{3}{*}{ № } & \multirow{3}{*}{ Types of dictionaries } & \multicolumn{10}{|c|}{ Students (\%) } \\
\hline & & \multicolumn{2}{|c|}{5} & \multicolumn{2}{|c|}{4} & \multicolumn{2}{|c|}{3} & \multicolumn{2}{|r|}{2} & \multicolumn{2}{|c|}{1} \\
\hline & & CG & EG & CG & EG & CG & EG & CG & EG & CG & EG \\
\hline 1. & Bilingual & 46,1 & 71,8 & 40,7 & 19,2 & 7,7 & 7,7 & 5,5 & - & - & 1,3 \\
\hline 2. & Monolingual & 15,8 & 33,3 & 21,4 & 51,3 & 40,7 & 12,8 & 12 & 2,6 & 10,1 & - \\
\hline 3. & Special & 5,5 & 19,2 & 6,6 & 33,3 & 52,7 & 42,3 & 19,8 & 5,2 & 15,4 & - \\
\hline 4. & Others: & 2,2 & 5,2 & 8,8 & 16,7 & 11 & 20,5 & - & 15,4 & - & 1,3 \\
\hline
\end{tabular}

The analysis of Table 1 shows that, at this stage of foreign language training, the overwhelming majority of EG students, compared with those of CG, consider different types of dictionaries to be the most useful: bilingual $-91 \%$ of students in EG and $86,8 \%$ of CG students, monolingual $-84,6 \%$ of students in EG and $37,2 \%$ of CG, and special ones $-52,5 \%$ of EG students and $12,1 \%$ of CG. In our opinion, such a correlation is caused by the EG students' better understanding of the necessity of the constant use of dictionaries of different types for self-development and upgrading their professional knowledge as well as argumentation of their personal position regarding the need for qualitative education and the prospects for professional formation.

We also asked students to indicate how useful can other types of dictionaries be in the process of foreign language teaching. 59,1\% of EG students and $22 \%$ of those in CG made marks on the scale, but the expanded answer was written only by individual students who mentioned only two types of dictionaries: technical and online. Other 40,9\% of EG students and 78\% of those in CG have no desire to use other types of dictionaries, which, besides those mentioned in the questionnaire, are also the sources of additional information. Perhaps, this can be explained by the lack of students' interest in a foreign language in general or the lack of interest in doing individual tasks in the subject. In order to significantly raise and maintain a general level of foreign language knowledge of the students of non-linguistic specialties, teachers should also focus students' attention on finding the necessary information in such types of dictionaries as dictionaries of synonyms, idioms, phrasal verbs, etc., which are more often used by the students of linguistic specialties.

We believe that special attention in the process of teaching the subject "Profession-Oriented Foreign Language Study" should be paid to special dictionaries as a means of training, with which students can 
expand their foreign language professional vocabulary. Therefore, students need to use special dictionaries throughout the entire course of studying a foreign language for professional purposes and to develop their abilities and skills of using dictionaries of this type, which will enable them to fully form the basis of information culture in their specialty in the future.

As different types of dictionary activity allow students to use functional possibilities of a dictionary as widely as possible, the next task at the end of the experiment was to find out how encouraging different types of dictionary activity are, when learning a foreign language. The students had to evaluate the suggested types of dictionary activity according to the five-point grading scale ( 5 - the most encouraging, 1 - the least encouraging).

The results of the questionnaire data analysis, supported by observations and conversations, presented in Table 2, show that in everyday foreign language practice students perform a limited number of dictionary activities. It can be concluded that there is a tendency for the most willing students to complete only three types of dictionary activity - search for a word in a native or foreign language (84,6\% of students in both CG and EG), search for correct spelling (69,2\% of students in EG and 50,6\% of CG students), search for correct pronunciation of words (59\% of students in EG and 56,1\% CG). Less commonly a dictionary is applied to find an example of a word usage in a sentence (50\% of students in EG and 30,8\% of those in CG) and search for a word combination with other words (41\% of students in EG and 19,8\% in CG). Students were mostly indifferent to such types of dictionary activity as search for grammatical characteristics of a word (33,3\% of students in EG and 16,5\% of those in CG) and derivatives (single-root words) (26,9\% of students in EG and $13,2 \%$ of CG students).

Table 2

Students' assessment of different types of dictionary activity performed in the process of foreign language training

\begin{tabular}{|c|c|c|c|c|c|c|c|c|c|c|c|}
\hline \multirow{3}{*}{ № } & \multirow{3}{*}{ Types of dictionary activity } & \multicolumn{10}{|c|}{ Students (\%) } \\
\hline & & \multicolumn{2}{|c|}{5} & \multicolumn{2}{|c|}{4} & \multicolumn{2}{|c|}{3} & \multicolumn{2}{|c|}{2} & \multicolumn{2}{|c|}{1} \\
\hline & & CG & EG & CG & EG & CG & EG & CG & EG & CG & $\mathbf{E G}$ \\
\hline 1. & $\begin{array}{l}\text { Search for a word in a native } \\
\text { (foreign) language }\end{array}$ & 46,1 & 44,9 & 38,5 & 39,7 & 8,8 & 12,8 & 6,6 & 2,6 & - & - \\
\hline 2. & $\begin{array}{l}\text { Search for correct spelling of a } \\
\text { word }\end{array}$ & 24,2 & $\overline{25,6}$ & 26,4 & 43,6 & 32,9 & 26,9 & 16,4 & 2,6 & - & 1,3 \\
\hline 3. & $\begin{array}{l}\text { Search for correct pronunciation of } \\
\text { a word }\end{array}$ & 28,6 & 30,8 & 27,5 & 28,2 & 22 & 25,6 & 13,2 & 12,8 & 8,7 & 2,6 \\
\hline 4. & $\begin{array}{l}\text { Search for an example of a word } \\
\text { usage in a sentence }\end{array}$ & 13,2 & 19,2 & 17,6 & 30,8 & 35,2 & 30,8 & 1,2 & 16,6 & 22 & 2,6 \\
\hline 5. & $\begin{array}{l}\text { Search for grammatical } \\
\text { characteristics of a word }\end{array}$ & 6,6 & 14,1 & 9,9 & 19,2 & 18,7 & 37,2 & 46,1 & 25,6 & 18,7 & 3,9 \\
\hline 6. & $\begin{array}{l}\text { Search for a word combination with } \\
\text { other words }\end{array}$ & 6,6 & 15,4 & 13,2 & 25,6 & 17,6 & 38,5 & 38,2 & 15,4 & 27,4 & 5,1 \\
\hline 7. & $\begin{array}{l}\text { Search for derivatives (single-root } \\
\text { words) }\end{array}$ & 4,4 & 6,4 & 8,8 & 20,5 & 10,9 & 25,6 & 49,5 & 33,3 & 26,4 & 14,2 \\
\hline
\end{tabular}

The analysis of the results presented in Table 2 allows us to make a generalisation that most of the students in EG have a much greater interest in performing all types of dictionary activity than the students in CG. It is quite obvious, that, as a result of the implementation of the educational technology with the use of dictionaries, the students of EG, compared with those of CG, perform the specified types of dictionary activity more willingly because they are more aware of the structural components of a dictionary, its main sections, the structure of a dictionary entry, types of dictionaries, and are able, without any problems, to find the necessary information, which, of course, enhances students' interest and desire in learning the language material carefully at high theoretical and practical levels with the help of dictionaries of different types.

When conducting dictionary activity with the students of non-linguistic specialties, it is very important to follow the principle of profession oriented educational activity which suggests "professional painting" of all kinds of activities at the foreign language classes: at each stage of the lesson any work should reflect the structure and functions of real professional communication in a foreign environment (Nikolayenko, 2013, p.105).

During the experiment, we made an assumption that students, who work with a dictionary, could have some difficulties. So, at the end of the experiment, we found out what difficulties students experienced while 
working with a dictionary. It turned out that, after the implementation of the educational technology with the use of dictionaries, the minimum number of respondents in EG (12\%), compared with the respondents in CG $(52,7 \%)$, had difficulties in the process of dictionary activity. The following difficulties were ticked in the questionnaire by the respondents: ignorance of dictionary structure, misunderstanding of the meaning of a word in a foreign language, lack of knowledge of the transcription of a word. At the request to mention other difficulties, only $14,3 \%$ of students in EG and $22 \%$ of those in CG pointed out poorly developed abilities and skills of dictionary activity, which undoubtedly have a decisive influence on the efficiency of the use of different types of dictionaries. The most important reasons for these difficulties were identified only by individual students: the impossibility to buy qualitative dictionaries because of high prices, lack of foreign language skills for realising the intention of working with a dictionary, lack of responsible attitude of students to foreign language classes, and indifference to the study of foreign languages.

At the end of the academic year, final control of the students' knowledge results in the subject "Profession-Oriented Foreign Language Study" was conducted through the tasks of computer testing. The database for computer testing tasks included 6 topics (Word Groups, Definitions, Sentence Supplement, Word Order, Lexical or Grammatical Mistake, Verb Tense Form), which covered testing both general knowledge of a foreign language and knowledge of the curriculum material. The results of students' progress in EG and CG are given in Figure 1:

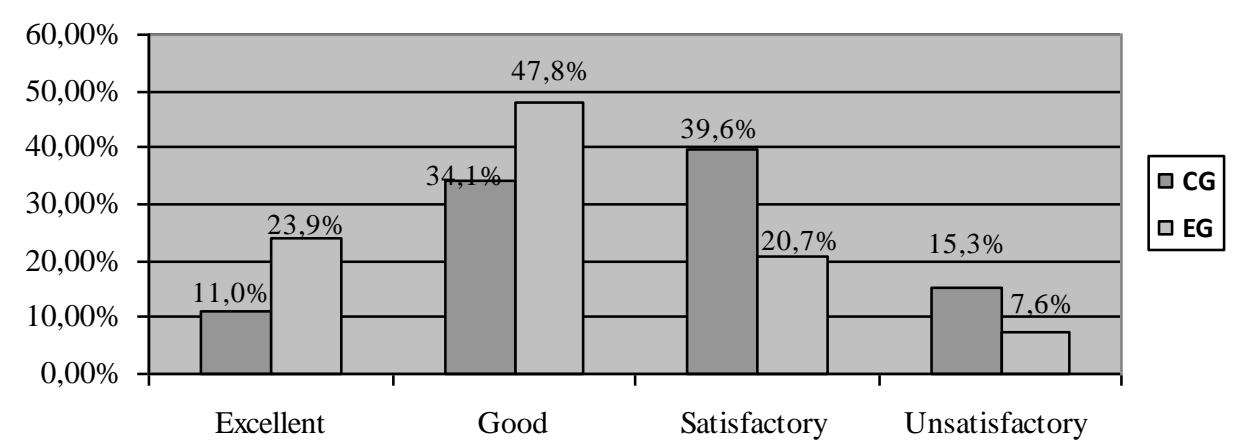

Figure 1. The results of students' progress in the discipline "Profession-Oriented Foreign Language Study"

As it can be seen from the data presented above, the students in EG showed significantly better results of foreign language study than the students in CG: $23,9 \%$ of students in EG and 11\% of those in CG got "excellent" marks, $47,8 \%$ of students in EG and 34,1\% of CG students were rated "good". Significant is the number of students in CG who received a satisfactory result $(39,6 \%)$, as compared to the number of students in EG (20,7\%). The number of students who received an "unsatisfactory" rating in CG $(15,3 \%)$ is twice as much as the same number of students in EG $(7,6 \%)$. Accordingly, the average score of academic progress in EG is 3,88 points, in $\mathrm{CG}-3,40$ points. Thus, it can be concluded that the average score in EG grew by 0,48 points in comparison with CG.

For considering the arithmetic mean values in EG and CG, the statistical processing of the final results of the study with the help of Student's t-test was used. When comparing the obtained results with confidence limits for the Student's t-test, we conclude that we obtained a statistically significant difference of value, as the empirical value (temp $=3.7)$ is greater than the critical value $(\mathrm{tcr}=2.6)$.

Thus, it can be stated that the method used in EG is more effective than the traditional one used in CG. Consequently, the hypothesis of the study about the effectiveness of the implementation of educational technology with the use of dictionaries in the process of foreign language training is confirmed.

According to the research results, we may conclude that the educational technology with the use of dictionaries has, undoubtedly, contributed to a higher level of foreign language proficiency of the students of non-linguistic specialties. Of course, we are aware of the fact that the quality of students' foreign language knowledge can be influenced by many other factors such as different level of foreign language proficiency, interest or indifference to the study of foreign languages. Moreover, each student differently organises and plans his/her educational activity with characteristic tempo of language material learning. However, it is impossible to deny the fact that dictionary is a means of personal development, and systematic, regular work with it develops thinking, memory, imagination, that is, develops intelligence, activates creative thinking of students and helps them obtain deep knowledge when studying a foreign language.

Special attention should be paid to making recommendations for a choice of the appropriate dictionary among a variety of dictionaries available on the book market and for the ways of using them effectively. In 
this context Lea (2002), the editor of the Oxford Learner's Dictionary of Academic English, underlines that each dictionary is to be a practical tool so that it could present the required information in as simple and accessible a way as possible (p. 829). The author emphasises that there are two important things to bear in mind: first, it needs to be the right dictionary for students' needs; second, students need to be aware of all the different types of information it contains and how to make the best use of it all.

Finally, the results of the experimental teaching show that foreign language training of the students of non-linguistic specialties through educational technology with the use of dictionaries enables students to perceive, understand, operate, analyse and absorb a significant amount of information which is constantly increasing, especially in the field of the chosen profession. At the same time, application of the suggested technology ensures continuity and consistency of a foreign language acquisition for a long time at a high level, and a gradual transition from training to future professional activities.

\section{Conclusions}

Summarising the results of the research, it is possible to conclude that the increase in students' foreign language proficiency should be based on the use of innovative educational technologies which would certainly consider the application of dictionaries as the facilities they provide in teaching and learning foreign languages and other subjects are noteworthy.

Findings of the present study will be beneficial for the students and teachers of a higher school as educational technology with the use of dictionaries under methodically correct conditions of its application can significantly improve the qualitative indicators of the educational process. We can assume that the suggested technology leads to the gradual formation of students' foreign language abilities and skills, to the development of their autonomous learning and responsible attitude to the process of study.

Taking into consideration the results of the conducted research, we can state that educational technology with the use of dictionaries is an indispensable learning tool that, according to its characteristics and educational potential, can be an effective means of enhancing the level of foreign language proficiency of the students of non-linguistic specialties.

The prospects of the future research concern diversification of the subject area of the application of the educational technology with the use of dictionaries and the search for a successful combination of this technology with other educational technologies that will ultimately improve the effectiveness of foreign languages education of the students of non-linguistic specialties and result in a qualitative training for their future professional activity.

\section{References:}

Abasova, I. (2013). Educational technology and other learning resources. Prezi: Presentation Software. Retrieved 15 April 2017 from https://prezi.com/ikv7ubmbzsb6/educational-technology-and-other-learning-resources/

Bondar, V.I. (2005). Dydaktyka [Didactics]. Kyiv, Ukraine: Lybid.

Borko, H. (2009). Wicked Problems and Other Thoughts on Issues of Technology and Teacher Learning. Journal of Teacher Education, 60 (1), 3-7. https://doi.org/10.1177/0022487108328488

Harmer, J. (2004). The practice of English language teaching. Pearson Education Limited: Longman.

Kitaygorodskaya, G.A. (1986). Metodicheskiye osnovy intensivnogo obucheniya inostrannym yazykam [Methodical bases of intensive training in foreign languages]. Moskva, Russia: Izd-vo Mosk. Un-ta.

Kyrykylytsia, V.V. (2013). Aktyvizatsiia navchalno-piznavalnoi diialnosti studentiv nemovnykh spetsialnostei u procesi roboty zi slovnykamy [Activation of knowledge and cognitive activity of non-language specialties' students in the process of working with dictionaries]. Unpublished candidate dissertation, Ternopil, Ukraine.

Kyrykylytsia, V.V. \& Yatsyniak, O.P. (2016). Anhliiska mova z vykorystannaim slovnykiv dlia studentiv khimichnoho fakultetu: navchalnyi posibnyk [English with Dictionaries Use for the Students of Chemistry]. Lutsk, Ukraine: Vezha-druk.

Landau, S.I. (2012). Slovnyky: mystetstvo ta remeslo leksykohrafii [Dictionaries: The Art and Craft of Lexicography]. Kyiv, Ukraine: K. I. S.

Lea, D. \& Runcie, M. (2002). Blunt Instruments and Fine Distinctions: a Collocations Dictionary for Students of English. Proceedings of the 10th EURALEX International Congress, 819-829.

Learning Technology Effectiveness (June 30, 2014). A report developed under the guidance of Richard Cullata and Bernadette Adams of the US Department of Education, Office of Educational Technology. Retrieved 15 April, 2017 from https://tech.ed.gov/wp-content/uploads/2014/11/Learning-Technology-Effectiveness-Brief.pdf

Mykytenko, N.O. (2015). Yakisni pokaznyky tekhnolohii efektyvnosti formuvannia inshomovnoi profesiinoi kompetentnosti maibutnikh fakhivtsiv pryrodnychoho profiliu [Qualitative indicators of efficiency of technologies developing ESP competence in students majoring in sciences]. Naukovi zapysky Ternopilskoho natsionalnoho pedahohichnoho universytetu imeni Volodymyra Hnatiuka. Ser.: Pedahohika, 1, 111-119.

Nikolayenko, Y. (2013). Pryntsypy pidhotovky studentiv ahrarnykh spetsialnostei do profesiinoho spilkuvannia v inshomovnomu seredovyshchi [The principles of training students of agrarian specialities for professional communication in foreign linguistic environment]. Pedahohika vyshchoi ta serednoi shkoly: zbirnyk naukovykh prac, 37, 102-106.

Nikolayeva, S. (2008). Osnovy suchasnoi metodyky vykladannia inozemnykh mov (skhemy i tablytsi) [Fundamentals of Modern Teaching Methods of Foreign Languages (schemes and tables). Kyiv, Ukraine: Lenvit.

Nisimchuk, A.S., Padalka, O.S. \& Shpak, O.T. (2000). Suchasni pedahohichni tekhnolohii [Modern pedagogical technologies]. Kyiv, Ukraine: Prosvita. 
Panova, L.S., Andriiko, I.F. \& Tezikova, S.V. (2010). Metodyka navchannia inozemnykh mov u zahalnoosvitnikh navchalnykh zakladakh [Methodology of teaching foreign languages in general educational institutions]. Kyiv, Ukraine: VTs "Akademia".

Pasichnyk, O.O. (2014). Do pytannia pidvyshchennia inshomovnoi kompetentnosti studentiv nemovnykh spetsialnostei: bariery ta shlakhy ikh podolannia [Methods of improving foreign language competence for nonlinguistic students: barriers and ways of their overcoming]. Zbirnyk naukovykh prac "Pedahohichni nauky", 66, 375-379. Kherson: KhDU.

Piekhota, O.M., Kiktenko, A. Z. \& Liubarska, O.M. (2001). Osvitni tekhnolohii [Educational technologies]. Kyiv, Ukraine: A.S.K.

Polat, Ye.S., Bukharkina, M.Yu., Moiseyeva, M.V. \& Petrov, A.Ye. Novye pedagogicheskiye i informatsionnye tekhnologii v sisteme obrazovaniya [New pedagogical and information technologies in the education system]. Moskva, Russia: Akademiya.

Rogova, G.V. (1991). Metodika obucheniya inostrannym yazykam v shkole [Methods of teaching foreign languages in school]. Moskva, Russia: Prosveshcheniye.

Standards Ukraine (2015). Pro orhanizatsiiu vyvchennia humanitarnykh dystsyplin. Lyst MON Ukrainy № 1/9-120 vid 11.03.15 r. [About the organization of studying humanitarian disciplines. Recommendation letter of Ministry of Education and Science of Ukraine, 1/9-120, dated 11 March 2015]. Retrieved 11 March 2015 from http://old.mon.gov.ua/files/normative/2015-0311/3666/lmon_1_9_120_11032015.pdf

Synekop, O. (2015). Effective writing of students of technical specialities. Advanced Education, 4, 51-55. http://dx.doi.org/10.20535/2410-8286.60757

Tarnopolskyi, O.B. (2006). Metodyka navchannia inshomovnoi movlennievoi diialnosti u vyshchomu movnomu zakladi osvity [Methodology of teaching foreign language speech activity in a higher linguistic educational institution]. Kyiv, Ukraine: "Inkos".

Vyshnevskyi, O.I. (2011). Metodyka navchannia inozemnykh mov [Methods of Teaching Foreign Languages]. Kyiv, Ukraine: Znannia.

Received: March 30, 2017

Accepted: October 27, 2017 